\title{
Performance of Denitrifying Microbial Fuel Cell with Biocathode over Nitrite
}

\author{
Huimin Zhao ${ }^{1,2}$, Jianqiang Zhao ${ }^{1 *}$, Fenghai $\mathrm{Li}^{2}$ and Xiaoling $\mathrm{Li}^{1}$ \\ ${ }^{1}$ Department of Environmental Engineering, School of Environmental Science and Engineering, Chang'an University, Xi'an, \\ China, ${ }^{2}$ Department of Chemistry and Chemical Engineering, Heze University, Heze, China
}

Microbial fuel cell (MFC) with nitrite as an electron acceptor in cathode provided a new technology for nitrogen removal and electricity production simultaneously. The influences of influent nitrite concentration and external resistance on the performance of denitrifying MFC were investigated. The optimal effectiveness were obtained with the maximum total nitrogen (TN) removal rate of $54.80 \pm 0.01 \mathrm{~g} \mathrm{~m}^{-3} \mathrm{~d}^{-1}$. It would be rather desirable for the TN removal than electricity generation at lower external resistance. Denaturing gradient gel electrophoresis suggested that Proteobacteria was the predominant phylum, accounting for $35.72 \%$. Thiobacillus and Afipia might benefit to nitrite removal. The presence of nitrifying Devosia indicated that nitrite was oxidized to nitrate via a biochemical mechanism in the cathode. Ignavibacterium and Anaerolineaceae was found

OPEN ACCESS

Edited by:

Yong Xiao,

Chinese Academy of Sciences, China

Reviewed by:

S. Venkata Mohan,

CSIR-Indian Institute of Chemical

Technology, India

Jie Wang,

Tianjin Polytechnic University, China

*Correspondence:

Jianqiang Zhao

626710287@qq.com

Specialty section:

This article was submitted to Microbiotechnology, Ecotoxicology

and Bioremediation,

a section of the journal

Frontiers in Microbiology

Received: 17 September 2015 Accepted: 03 March 2016 Published: 22 March 2016

Citation:

Zhao H, Zhao J, Li F and LiX (2016) Performance of Denitrifying Microbial Fuel Cell with Biocathode over Nitrite.

Front. Microbiol. 7:344.

doi: 10.3389/fmicb.2016.00344 in the cathode as a heterotrophic bacterium with sodium acetate as substrate, which illustrated that sodium acetate in anode was likely permeated through proton exchange membrane to the cathode.

Keywords: microbial fuel cell, autotrophic denitrification, nitrite, nitration, biocathode

\section{INTRODUCTION}

Microbial fuel cell (MFC) possesses great potential in the application of wastewater treatment because of its unique capability of converting the chemical energy of organic waste into electrical energy (Logan et al., 2006). It has been proved that both nitrate and nitrite can be removed from wastewater as electron acceptors in the cathode of MFCs through electrochemical reduction or autotrophic denitrification (Wang et al., 2009; Desloover et al., 2011; Zhao et al., 2011). In MFC, the organic substrates are oxidized by exoelectrogenic microbes in the anode chamber to produce electrons and protons. Electrons produced are transferred through the external circuit to the cathode while protons move through the proton exchange membrane to the cathode, where they combine to an electron acceptor (e.g., nitrate or nitrite) to complete the circuit (Van Doan et al., 2013). Virdis et al. (2008) discovered that nitrite could serve as an efficient terminal electron acceptor at the cathode of MFC, which further reduced the carbon-nitrogen ratio demand. The similar results were also demonstrated by Puig et al. (2011) and Desloover et al. (2011). The biotic cathode using nitrite as an electron acceptor showed a TN removal percentage of $48 \%$ and a removal rate of $7.6 \mathrm{~g}\left(\mathrm{NO}_{2}^{-}-\mathrm{N}\right) \mathrm{m}^{-3} \mathrm{~d}^{-1}$ during the $4 \mathrm{~h}$ continuing mode of operation (Puig et al., 2011). Although the TN removal rate via cathodic (autotrophic) denitrification in MFC is generally lower than that via heterotrophic denitrification, it is very important to notice that autotrophic microbes need few carbon source and their slow growth results in small sludge production (Wang et al., 2009; Zhao et al., 2011). Consequently, autotrophic denitrifying MFCs are promising technologies to treat low organic carbon wastewater, which greatly reduced the dependence on carbon in denitrifying process. 
However, nitrite is oxidized easily by biological or electrochemical processes which significantly degraded the TN removal and electricity generation efficiency. Puig et al. (2011) found that about $52 \%$ nitrite oxidized to nitrate in the MFC cathode at an external resistance of $100 \Omega$. And he speculated that disappeared nitrite was oxidized by nitrite oxidizing bacteria (NOBs) or by other electrochemical processes. Li et al. (2014) also found that about $80 \%$ nitrite oxidized to nitrate. To inhibit the nitrification, one way was to add sodium azide in the cathode (Guisasola et al., 2005; Puig et al., 2011), the other way was to change the operating conditions of a cathode chamber(e.g, external resistance and HRT and temperature; Li et al., 2014). In order to further clarify these influencing factors of denitrifying MFC and the mechanism of nitrite conversion to nitrate in the cathode of MFC without the addition of chemical inhibitors, this study aimed to investigate the performance of the denitrification of MFC, which based on electricity generation and nitrite removal with different nitrite concentrations and external resistances in the denitrifying MFC at the long duration of the operation. PCR-DGGE was used to assess the cathode microbial community to speculate for possible reactions in the cathode.

\section{MATERIALS AND METHODS \\ Structure of MFC and Operation}

The MFC consisting of an anode chamber and a cathode chamber placed on opposite sides of a single methacrylate rectangular chamber with dimensions of $15 \mathrm{~cm}$ high, $5 \mathrm{~cm}$ long, and $2.5 \mathrm{~cm}$ wide. A proton exchange membrane (nafion117, DuPont, USA) was used as a separator between anode and cathode chambers. Each chamber was filled with rectangular graphite felts $(140 \mathrm{~mm}$ long, $11.7 \mathrm{~mm}$ wide, and $5 \mathrm{~mm}$ thick) as electrode and inserted with a graphite rod, which led to the eventual volume of $160 \mathrm{~cm}^{3}$ for cathodic and anodic chamber, respectively. The electrodes were sequentially washed in $1 \mathrm{M} \mathrm{HCl}$ and $1 \mathrm{M} \mathrm{NaOH}$ to remove possible metal and biomass contamination (Bond and Lovley, 2003). The cathodic and the anodic electrodes were connected to the external resistor to close the electric circuit. A $\mathrm{Hg} / \mathrm{Hg} \mathrm{Cl}$ electrode $(+0.242 \mathrm{~V}$ vs. SHE) was used as a reference electrode placing in the cathode solution. Three peristaltic pumps (Lan Ge YZ1515X, Baoding, China) were used to continuously supply influents to anode and cathode chambers, and reflux the cathode solution. All experiments were performed at $32 \pm$ $1^{\circ} \mathrm{C}$. Figure 1 showed the schematic diagram of the MFC in this study.

The electrode material was immersed in corresponding seeding sludge (anaerobic sludge from Xi'an Hans Brewery Wastewater Treatment, China) for $48 \mathrm{~h}$ to absorb bacteria and then loaded in corresponding chambers. The starting procedure of the MFC was followed as reported by Virdis et al. (2008). The flow rate of influent was maintained at $3 \mathrm{~mL} \mathrm{~h}^{-1}$. The initial resistance was set at $1000 \Omega$ for 15 days and then turned to 100 $\Omega$ for about a month. When the output voltage of the MFC was stable and reached $200 \mathrm{mV}$ with external resistance of $100 \Omega$, the start-up of the MFC was considered to be successful. Then, the resistance was kept constant at $10 \Omega$, and maintained for 240 days. A series of experiments were performed, the performance of MFC was studied in terms of changing the nitrite nitrogen concentrations of $\left(60,90\right.$, and $\left.180 \mathrm{mg} \mathrm{L}^{-1}\right)$ at external resistance of $10 \Omega$. Afterward, the effect of external resistance was studied by varying external resistances in the range from 5 to $10,25,50$, 100 , and $200 \Omega$.

The anode solution was composed of $\mathrm{CH}_{3} \mathrm{COONa}(3.84 \mathrm{~g}$ $\left.\mathrm{L}^{-1}\right), \mathrm{KCl}\left(0.13 \mathrm{~g} \mathrm{~L}^{-1}\right), \mathrm{MgSO}_{4} \cdot 7 \mathrm{H}_{2} \mathrm{O}\left(0.1 \mathrm{~g} \mathrm{~L}^{-1}\right), \mathrm{CaCl}_{2}(0.015 \mathrm{~g}$ $\left.\mathrm{L}^{-1}\right), \mathrm{K}_{2} \mathrm{HPO}_{4} \cdot 3 \mathrm{H}_{2} \mathrm{O}\left(8.57 \mathrm{~g} \mathrm{~L}^{-1}\right), \mathrm{KH}_{2} \mathrm{PO}_{4}\left(2.88 \mathrm{~g} \mathrm{~L}^{-1}\right)$, and trace elements $1 \mathrm{~mL} \mathrm{~L}^{-1}$.

The cathode solution was composed of $\mathrm{NaNO}_{2}\left(0.15 \mathrm{~g} \mathrm{~L}^{-1}\right)$, $\mathrm{NaHCO}_{3}\left(1 \mathrm{~g} \mathrm{~L}^{-1}\right), \mathrm{MgSO}_{4} \cdot 7 \mathrm{H}_{2} \mathrm{O}\left(0.1 \mathrm{~g} \mathrm{~L}^{-1}\right), \mathrm{CaCl}_{2}(0.015 \mathrm{~g}$ $\left.\mathrm{L}^{-1}\right), \mathrm{K}_{2} \mathrm{HPO}_{4} \cdot 3 \mathrm{H}_{2} \mathrm{O}\left(8.57 \mathrm{~g} \mathrm{~L}^{-1}\right), \mathrm{KH}_{2} \mathrm{PO}_{4}\left(2.88 \mathrm{~g} \mathrm{~L}^{-1}\right)$, and trace elements $1 \mathrm{~mL} \mathrm{~L}^{-1}$.

\section{Data Calculation and Analysis}

The voltage $(\mathrm{V})$ and cathode potentials of the MFC were monitored at $1 \mathrm{~min}$ intervals and $10 \mathrm{~min}$ averaged with a data acquisition system (Yanhua PCI1713, China). Current (I) and power $(\mathrm{P}=\mathrm{I} \cdot \mathrm{V})$ were determined according to Ohm's law. Power and current densities were calculated by dividing power or current by the net cathodic volume. The cathodic Coulombic efficiencies was calculated according to Logan et al. (2006). DO was determined using Hach-HQ30d (HACH, USA). The concentrations of $\mathrm{NO}_{2}^{-}-\mathrm{N}$ and $\mathrm{NO}_{3}^{-}-\mathrm{N}$ were measured according to standard methods (APHA, 1998). During the experimental, all analyses under the same operations were carried out more than triplicate.

\section{DNA Analysis}

After being operated stably for 9 months at the external resistance of $10 \Omega$ and the flow rate of $3 \mathrm{~mL} \mathrm{~h}^{-1}$ and the nitrite nitrogen concentrations of $188 \mathrm{mg} \mathrm{L}^{-1}$, biofilm sample from the suspension liquid of the cathode was taken to be investigated with denaturing gradient gel electrophoresis (DGGE), and DNA was extracted using a fast DNA spin kit (SK8233) for soil according to the manufacturer's instructions. The bacterial 16S rRNA genes were amplified by polymerase chain reaction (PCR) techniques with the universal primers F357GC (5'-CGCCCGCCGCGCCCCGCG CCCGGCCCGCCGCCC CGCCCCCCTACGGGAGGCAGCAG-3') and R518 (5'-ATT ACCGCG GCTGCTGG-3'). Polyacrylamide gel (8\%) with a $30-60 \%$ denaturing gradient was used to separate the PCR products ( $7 \mathrm{~mol} \mathrm{~L}^{-1}$ urea and $40 \%$ formamide comprising $100 \%$ denaturant), and the PCR product was analyzed by the DGGE technology and washed with ultrapure water for flushing the gel and dye. The eight representative DGGE strips were selected by a clean scalpel to select and transfer in a $1.5 \mathrm{~mL}$ centrifuge tube. Then, the target DNA fragments were excised and reamplified by using the primer sets F357 (5'-CCTACGGGAGGCAGC AG-3') and R518 (5'-ATTACCGCGGCTGCTGG-3'), and the obtained sequence was matched with the Seqmatch database for sequence alignment. The homology information of each strip was obtained by Shanghai Sangong Biological Engineering Co., Ltd. China. This process was similar to that reported by Deng et al. (2016). 


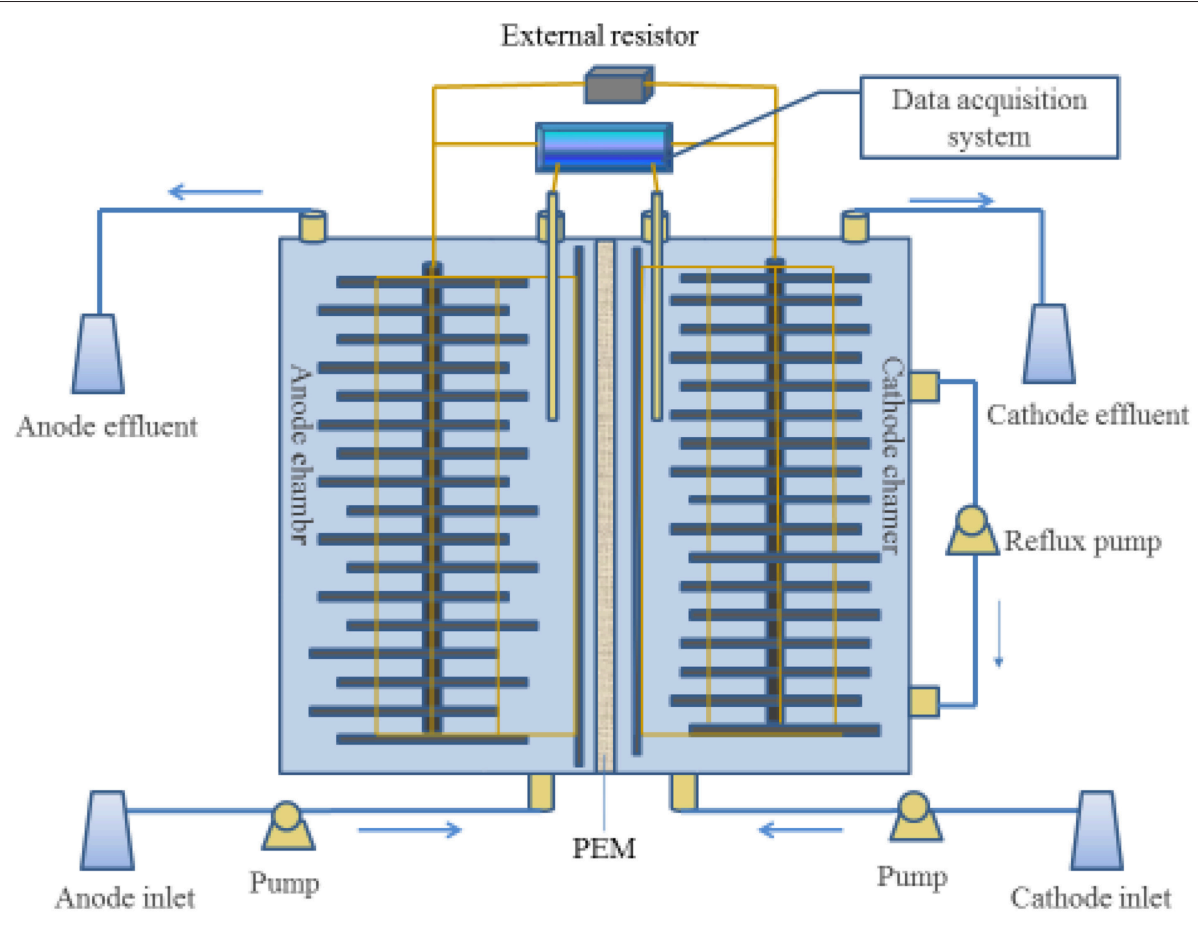

FIGURE 1 | Schematic of the double chamber MFC.

TABLE 1 | Electrical characteristics of the MFC with different nitrite concentrations.

Inflow rate $\left(\mathrm{mL} \mathrm{h}^{-1}\right) \quad$ Influent $\mathrm{NO}_{2}^{-}-\mathrm{N}\left(\mathrm{mg} \mathrm{L}^{-1}\right) \quad$ Cathode potential $(\mathrm{mV}) \quad$ Current density $\left(\mathrm{A} \mathrm{m}^{-3}\right)$ Power density (W $\left.\mathrm{m}^{-3}\right) \quad$ Columbic efficiency $(\%)$

\begin{tabular}{rrrrrr}
\hline 3 & $60.11 \pm 0.34$ & $-35.2 \pm 3.2$ & $18.02 \pm 0.81$ & $0.518 \pm 0.035$ & $279.5 \pm 32.15$ \\
3 & $86.65 \pm 0.61$ & $-47.22 \pm 5.3$ & $19.25 \pm 1.07$ & $0.594 \pm 0.071$ & $231.53 \pm 28.53$ \\
3 & $188.12 \pm 2.3$ & $-38.36 \pm 2.5$ & $18.40 \pm 0.36$ & $0.541 \pm 0.004$ & $140.12 \pm 0.71$ \\
\hline
\end{tabular}

TABLE 2 | Characteristics of denitrification with different nitrite concentrations.

\begin{tabular}{|c|c|c|c|c|c|c|}
\hline $\begin{array}{l}\text { Inflow rate } \\
\left(m L h^{-1}\right)\end{array}$ & $\begin{array}{l}\text { Influent } \mathrm{NO}_{2}^{-}-\mathrm{N} \\
\quad\left(\mathrm{mg} \mathrm{L}^{-1}\right)\end{array}$ & $\begin{array}{l}\text { Effluent } \mathrm{NO}_{2}^{-}-\mathrm{N} \\
\quad\left(\mathrm{mg} \mathrm{L}^{-1}\right)\end{array}$ & $\begin{array}{c}\Delta \mathrm{NO}_{3}^{-}-\mathrm{N} \\
\left(\mathrm{mg} \mathrm{L}^{-1}\right)\end{array}$ & $\begin{array}{c}\text { Nitrification } \\
\text { Percentage (\%) }\end{array}$ & $\begin{array}{l}\text { TN removal } \\
\left(\mathrm{g} \mathrm{m}^{-3} \mathrm{~d}^{-1}\right)\end{array}$ & $\begin{array}{c}\Delta \mathrm{pH} \\
\text { Effluent }\end{array}$ \\
\hline 3 & $60.11 \pm 0.34$ & 0 & $0.2 \pm 0.1$ & 0.33 & $26.91 \pm 1.72$ & 0.85 \\
\hline 3 & $188.12 \pm 2.3$ & $16.72 \pm 0.59$ & $49.5 \pm 0.5$ & 26.33 & $54.80 \pm 0.01$ & 1.18 \\
\hline
\end{tabular}

$\Delta \mathrm{NO}_{3}^{-}-\mathrm{N}=$ incremental nitrate.

\section{RESULTS AND DISCUSSION}

\section{Performance of Denitrification MFC with Different Nitrite Concentrations}

The results of different influent nitrite concentration at the inflow rate of $3 \mathrm{~mL} \mathrm{~h}^{-1}$ and the external resistance of $10 \Omega$ and temperature of $32^{\circ} \mathrm{C}$ were listed in Tables $\mathbf{1}, 2$.

As shown in Table 1, when the flow rate was $3 \mathrm{~mL} \cdot \mathrm{h}^{-1}$, the increase of influent nitrite concentration had little benefit on current density and power density. The cathode potential decreased with the increase of current density. The cathode coulombic efficiency was higher than $100 \%$ due to other oxidizing substances (e.g., oxygen) in the cathode functioning as a terminal electron acceptor especially when the nitrite concentration of the effluent was about zero (Table 2; Xie et al., 2011). Cha et al. (2010) found that microorganism using with oxygen as electron acceptor for oxygen utilization efficiency was very high, which might compete with denitrifying microorganism and affect the cathode denitrification.

The autotrophic denitrification of nitrite to nitrogen gas in the bio-cathode can be described by the following equations (reaction 1-3; Clauwaert et al., 2007). Table 2 showed that when 
the flow rate was maintained at $3 \mathrm{~mL} \mathrm{~h}^{-1}$, with increasing concentration of the influent nitrite, the $\mathrm{TN}$ removal rate increased significantly from $26.91 \pm 1.72 \mathrm{~g} \mathrm{~m}^{-3} \mathrm{~d}^{-1}$ to the maximum of $54.80 \pm 0.01 \mathrm{~g} \mathrm{~m}^{-3} \mathrm{~d}^{-1}$; but the nitrification percentage increased from 0.33 to $26.33 \%$ meanwhile. Therefore, considering two factors of nitrification and the TN removal, we operated the MFC at the high influent nitrite of $188 \mathrm{mg} \mathrm{L}^{-1}$ which would be favorable.

$$
\begin{array}{cc}
\text { Nitrite reduction: } \mathrm{NO}_{2}^{-}+e^{-}+2 \mathrm{H}^{+}=\mathrm{NO}+\mathrm{H}_{2} \mathrm{O} \\
E^{0}=+0.350 \mathrm{~V} \text { vs } \mathrm{SHE}
\end{array}
$$

Nitric oxide reduction: $\mathrm{NO}+e^{-}+\mathrm{H}^{+}=0.5 \mathrm{~N}_{2} \mathrm{O}+0.5 \mathrm{H}$

$$
E^{0}=+1.175 \mathrm{~V} \text { vs SHE }
$$

Nitrous oxide reduction:

$$
0.5 \mathrm{~N}_{2} \mathrm{O}+e^{-}+\mathrm{H}^{+}=0.5 \mathrm{~N}_{2}
$$$$
+0.5 \mathrm{H}_{2} \mathrm{O}
$$$$
E^{0}=+1.355 \mathrm{~V} \text { vs SHE }
$$

$$
\text { Nitrification process: } \quad \mathrm{NO}_{2}^{-}+0.5 \mathrm{O}_{2}=\mathrm{NO}_{3}^{-}
$$

Under the condition of strict measures to maintain the anoxic condition in the cathode, but the cathode still showed obvious nitrite nitrification. The small part of nitrite to nitrate transformation might be caused by biological nitrification in this study (reaction 4) because of trace oxygen in the cathode. While the other part of the nitrite transformation also might be oxidized by other electrochemical processes (Puig et al., 2011).

\section{Performance of Denitrification MFC at Different External Resistances}

When the influent nitrite nitrogen concentration and influent flow rate were $188 \pm 2.3 \mathrm{mg} \mathrm{L}^{-1}, 3 \mathrm{~mL} \mathrm{~h}^{-1}$, respectively. The results of denitrification at different external resistances were shown in Figures 2, 3, respectively.

Different external resistances cause different electron transfer rates and variations in microbial metabolic activities and kinetic differences in substrate utilization (Zhang et al., 2011). Usually, the pollutant removal of MFC is faster at the smaller external

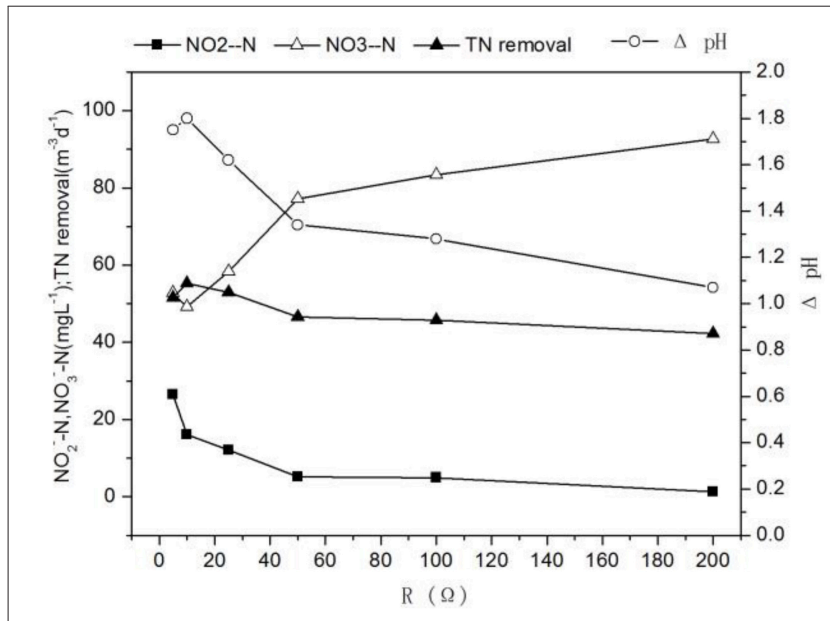

FIGURE 2 | Profiles of characteristics of cathode effluent with different external resistances. resistance which can reduce the extracellular electron transfer resistance and increase the electron transfer rate (Katuri et al., 2011). As external resistance was increased from 5 to $200 \Omega$, the concentrations of nitrite in effluent and the TN removal rate decreased significantly from $26.55 \pm 0.85$ to $1.26 \pm 0.09 \mathrm{mg} \mathrm{L}^{-1}$ and $51.51 \pm 0.17$ to $42.25 \pm 0.24 \mathrm{~g} \mathrm{~m}^{-3} \mathrm{~d}^{-1}$, whereas the nitrate concentration in effluent increased from $52.84 \pm 0.48$ to $92.62 \pm$ $1.47 \mathrm{mg} \mathrm{L}^{-1}$ (Figure 2), the increase of effluent $\mathrm{pH}$ changed with the increase of the TN removal rate, which showed that a large external resistance was not help to denitrification. Zhang and $\mathrm{He}$ (2012) found that the TN removal rate increased from 51.9 to $68 \%$ with decreasing external resistance from 712 to $10 \Omega$ in a dual chamber MFC. At the same time, the potential of cathode increased (excepting at $5 \Omega$ ) -35.49 to $31.11 \mathrm{mV}$, while the current density and the cathode coulombic efficiency decreased 15.666.7 $\mathrm{Am}^{-3}$ and 133.91 to $65.05 \%$. The low coulombic efficiency (65.05\%) indicated possible intermediate accumulation such as $\mathrm{N}_{2} \mathrm{O}$ and NO. Because the reduction of nitrite to $\mathrm{N}_{2}$ requires 3 mol electrons, whereas the reduction of nitrite to $\mathrm{NO}$ and $\mathrm{N}_{2} \mathrm{O}$ need $1 \mathrm{~mol}$ and $2 \mathrm{~mol}$ electron, respectively, which causing low current density and coulombic efficiency (Wrage et al., 2001). These results were in accordance with Virdis et al. (2010) who observed 29.2\% total nitrogen conversion to $\mathrm{N}_{2} \mathrm{O}$, Puig et al. (2011) also showed that the cathode coulombic efficiency was $\sim 48 \%$, confirming the existence of the intermediate product $\mathrm{NxO}$ in the process of denitrification, causing the cathode coulombic efficiency to be below $100 \%$.

It was found that the highest power $\operatorname{den} \operatorname{sity}\left(1.71 \mathrm{~W} \mathrm{~m}^{-3}\right)$ was obtained at $50 \Omega$ while the highest TN removal rate $(54.80 \pm$ $0.01 \mathrm{~g} \mathrm{~m}^{-3} \mathrm{~d}^{-1}$ ) was at $10 \Omega$ (Figures 2, 3). The result implied that operation of denitrifying MFC at a lower external resistance would be desirable for the TN removal but not electricity generation (Li et al., 2013). The performance of the MFC became poor when the external resistance was turned to $5 \Omega$, which indicated the MFC reaching the limit current. Therefore, if the aim of the MFC was the TN removal over electricity generation for a denitrifying MFC, operation would be desirable at lower external resistance (except generating limit current).

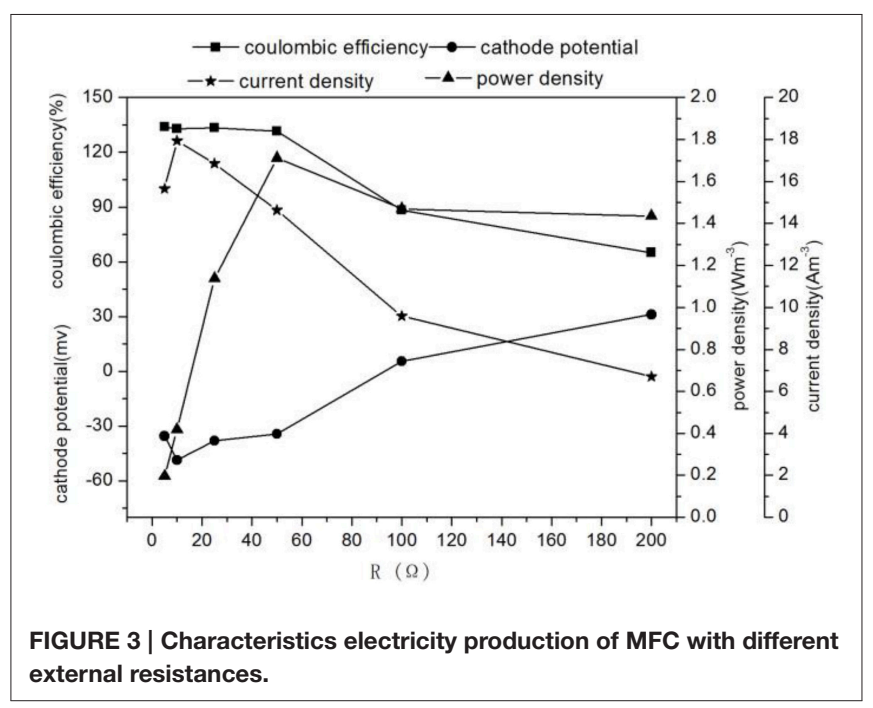


TABLE 3 | The identifications of DGGE bands.

\begin{tabular}{|c|c|c|c|c|c|}
\hline Band & Proportion (\%) & Taxon & Similarity (\%) & Accession & Phylum/Genus \\
\hline 5 & 8.19 & Uncultured bacterium & 100 & AY548931 & Ignavibacteriae/Ignavibacterium \\
\hline 22 & 8.95 & uncultured bacterium & 93 & EU283596 & Ignavibacteriae/Ignavibacterium \\
\hline 6 & 4.69 & Candidatus Devosia euplotis & 81 & AJ548823 & Proteobacteria/Devosia \\
\hline 19 & 8.86 & uncultured bacterium & 88 & AB487482 & Proteobacteria/Pelomonas \\
\hline 20 & 8.19 & uncultured bacterium & 83 & FJ516975 & Proteobacteria/Thiobacillus \\
\hline 29 & 13.98 & Afipia massiliensis & 100 & AB272322 & Proteobacteria/Afipia \\
\hline 9 & 7.96 & Uncultured bacterium & 100 & EU083501 & Deinococcus-Thermus /Truepera \\
\hline 18 & 23.02 & Uncultured bacterium & 93 & FN436167 & Deinococcus-Thermus/Truepera \\
\hline 16 & 7.06 & Bellilinea caldifistulae & 87 & AB355078 & Chloroflexi/Bellilinea \\
\hline 31 & 9.09 & uncultured bacterium & 88 & JQ408049 & Chloroflexi/Anaerolineaceae \\
\hline
\end{tabular}

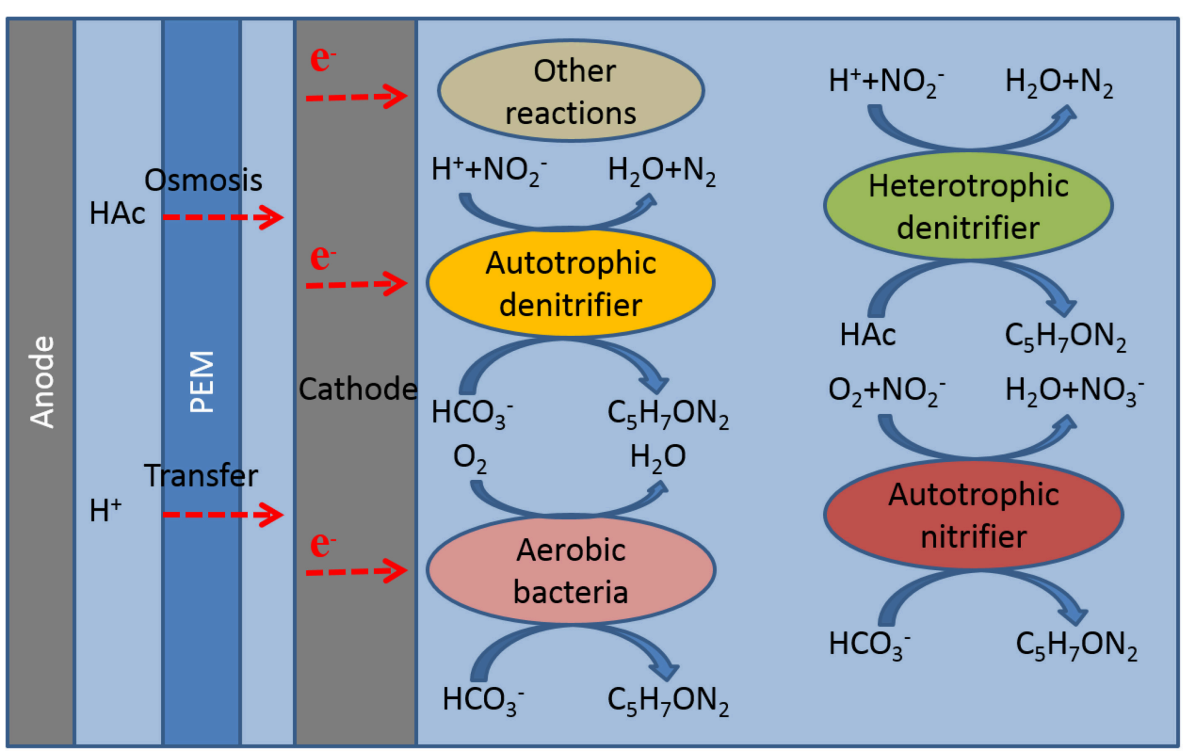

FIGURE 4 | Mechanism of the cathode chamber.

\section{Identification of Cathode Microbial Species}

The microbial communities of the nitrite bio-cathodes were analyzed by DGGE. As shown in Table 3. The microbial community structure was diversity in the cathode of MFC. In addition to these bands, the bio-cathode samples contained clones that were mostly assigned to known sequences, The bacterial communities were Devosia(bands 6), Pelomonas(bands 19), Thiobacillus(bands 20), and Afipia(bands 29) in Phylum Proteobacteria (35.72\%), Proteobacteria was found to be dominative in the denitrification of MFC cathode (Karanasios et al., 2010). Kondaveeti et al. (2014) also identified several members of Proteobacteria and Firmicutes in cathodic nitrate and nitrite reduction. Truepera(bands 9 and 18) related to Phylum Deinococcus-Thermus (30.98\%), Ignavibacterium(bands 5 and 22) similar to Phylum Ignavibacteriae (17.14\%), and Bellilinea(bands 16) and Anaerolineaceae (bands 31) corresponding to Phylum Chloroflexi (16.15\%).

Analysis of the microbial communities newly developed on the bio-cathodes revealed that most of them have previously been demonstrated to be capable of communicating with the electrode, For example, Afipia and Thiobacillus were dominant species responsible for autotrophic denitrifying in the cathode of MFC (Kelly and Wood, 2000; La Scola et al., 2002). Devosia had nitrification ability contributing to the nitration phenomenon in the experiment (Vanparys et al., 2005). Ignavibacterium (Okamoto et al., 2013) was distinctively detected on the bio-cathode and involved in heterotrophic denitrifying bacteria. Anaerolineaceae was the anaerobic methanogenesis for sodium acetate as the substrate (Yamada et al., 2006). The proportion of aerobic Truepera and Pelomonas was $39.64 \%$, which exhibited the ability of respiration with oxygen (Albuquerque et al., 2005; Chandra et al., 2011).

\section{Mechanism of the Cathode Chamber}

From the analysis of the microbial community composition and the experimental results, we speculated for possible reactions in the cathode of MFC (Figure 4). 
(1) Autotrophic denitrification: Known as autotrophic electrotrophs with an electrode as the electron donor in the cathode of MFC (Virdis et al., 2008; Puig et al., 2011). Afipia and Thiobacillus directly contributed to autotrophic denitrification. Several researchers also demonstrated the autotrophic bacterium dominated in the cathode microbial community (Wrighton et al., 2010).

(2) Heterotrophic denitrification: Organic matter was not added in the cathode, however, about $25 \mathrm{mg} \mathrm{L}^{-1}$ of COD was detected, so the existence of heterotrophic denitrifying bacteria Ignavibacterium might be caused by sodium acetate in the anode permeate through proton membrane to the cathode (Kim et al., 2007; Chae et al., 2008; Okamoto et al., 2013). Xiao et al. indicated the heterotrophic bacterium survival in the autotrophic denitrifying cathode of MFC (Xiao et al., 2015).

(3) Autotrophic nitrification: The high convert of nitrite to nitrate in this experiment and autotrophic nitrifying bacteria Devosia indicated nitrification happened in the cathode (Vanparys et al., 2005).

(4) Oxygen reduction: The cathode coulombic efficiency over $100 \%$ in most of the experiments and aerobic Truepera and Pelomonas indicated oxygen as the electron acceptor in the cathode (Albuquerque et al., 2005; Chandra et al., 2011; Xie et al., 2011).

(5) Other electrochemical reactions: Although oxygen was not detected in cathode through the whole experiment, the high cathode coulombic efficiency and nitrification rate showed the presence of other oxidant. We speculated that the oxidant might be produced from the other electrochemical reactions.

\section{REFERENCES}

Albuquerque, L., Simoes, C., Nobre, M. F., Pino, N. M., Battista, J. R., Silva, M. T., et al. (2005). Truepera radiovictrix gen. nov., sp. nov., a new radiation resistant species and the proposal of Trueperaceae fam. nov. FEMS Microbiol. Lett. 247, 161-169. doi: 10.1016/j.femsle.2005.05.002

APHA (1998). Standard Methods for the Examination of Water and Wastewater, 20th Edn. Washington, DC: United Book Press.

Bond, D. R., and Lovley, D. R. (2003). Electricity production by Geobacter sulfurreducens attached to electrodes. Appl. Environ. Microbiol. 69, 1548-1555. doi: 10.1128/AEM.69.3.1548-1555.2003

Cha, J., Choi, S., Yu, H. N., Kim, H., and Kim, C. (2010). Directly applicable microbial fuel cells in aeration tank for wastewater treatment. Bioelectrochemistry 78, 72-79. doi: 10.1016/j.bioelechem.2009.07.009

Chae, K. J., Choi, M., Ajayi, F. F., Park, W., Chang, I. S., and Kim, I. S. (2008). Mass transport through a proton exchange membrane (Nafion) in microbial fuel cells. Energy Fuels 22, 169-176. doi: 10.1021/ef700308u

Chandra, R., Bharagava, R. N., Kapley, A., and Purohit, H. J. (2011). Bacterial diversity, organic pollutants and their metabolites in two aeration lagoons of common effluent treatment plant (CETP) during the degradation and detoxification of tannery wastewater. Bioresour. Technol. 102, 2333-2341. doi: 10.1016/j.biortech.2010.10.087

Clauwaert, P., Rabaey, K., Aelterman, P., de Schamphelaire, L., Pham, T. H., Boeckx, P., et al. (2007). Biological denitrification in microbial fuel cells. Environ. Sci. Technol. 41, 3354-3360. doi: 10.1021/es062580r

Deng, Y., Zhang, X., Miao, Y., and Hu, B. (2016). Exploration of rapid start-up of the CANON process from activated sludge inoculum in a sequencing biofilm batch reactor (SBBR). Water Sci. Technol. 73, 535-542. doi: $10.2166 /$ wst. 2015.518

\section{CONCLUSIONS}

Nitrite reduction has been shown to be a bio-catalytic process in denitrifying MFCs that could produce bioelectricity. Nitrite could be oxidized in the cathode via biological or electrochemical processes; the maximum $\mathrm{TN}$ removal rate of $54.80 \pm 0.01 \mathrm{~g} \mathrm{~m}^{-3} \mathrm{~d}^{-1}$ was obtained. It would be desirable for the TN removal but not electricity generation at a lower external resistance in MFC. An analysis of biocathode biofilms indicated Proteobacteria was the dominant species, accounting for $35.72 \%$. Afipia and Thiobacillus mainly benefit to autotrophic denitrification in MFC. Truepera, Devosia, and Pelomonas might contribute to electricity generation. We speculated for possible reactions in the cathode according to the microbial community analysis and the experimental results.

\section{AUTHOR CONTRIBUTIONS}

$\mathrm{HZ}$ and JZ designed the experiment, and supervised conduct of the experiment. HZ supervised the data collection. HZ and JZ drafted the manuscript, FL and XL contributed substantially to the revision.

\section{ACKNOWLEDGMENTS}

This study was supported by the Fundamental Research Funds for the Central Universities (No. 2013G3292017) and the Fundamental Research Funds for Shanxi province department (2014K15-03-02).

Desloover, J., Puig, S., Virdis, B., Clauwaert, P., Boeckx, P., Verstraete, W., et al. (2011). Biocathodic nitrous oxide removal in bioelectrochemical systems. Environ. Sci. Technol. 45, 10557-10566. doi: 10.1021/es202047x

Guisasola, A., Jubany, I., Baeza, J. A., Carrera, J., and Lafuente, L. (2005). Respirometric estimation of the oxygen affinity constants for biological ammonium and nitrite oxidation. J. Chem. Technol. Biotechnol. 80, 388-396. doi: $10.1002 /$ jctb. 1202

Karanasios, K. A., Vasiliadou, I. A., Pavlou, S., and Vayenas, D. V. (2010). Hydrogenotrophic denitrification of potable water: a review. J. Hazard. Mater. 180, 20-37. doi: 10.1016/j.jhazmat.2010.04.090

Katuri, K. P., Scott, K., Head, I. M., Picioreanu, C., and Curtis, T. P. (2011). Microbial fuel cells meet with external resistance. Bioresour. Technol. 102, 2758-2766. doi: 10.1016/j.biortech.2010.10.147

Kelly, D. P., and Wood, A. P. (2000). Reclassification of some species of Thiobacillus to the newly designated genera Acidithiobacillus gen. nov., Halothiobacillusgen. nov. and Thermithiobacillus gen. nov. Int. J. Syst. Evol. Microbiol. 50, 511-516. doi: 10.1099/00207713-50-2-511

Kim, J. R., Cheng, S., Oh, S. E., and Logan, B. E. (2007). Power generation using different cation, anion and ultrafiltration membranes in microbial fuel cells. Environ. Sci. Technol. 41, 1004-1009. doi: 10.1021/es0 $62202 \mathrm{~m}$

Kondaveeti, S., Lee, S. H., Park, H. D., and Min, B. (2014). Bacterial communities in a bioelectrochemical denitrification system: the effects of supplemental electron acceptors. Water Res. 51, 25-36. doi: 10.1016/j.watres.2013. 12.023

La Scola, B., Mallet, M. N., Grimont, P. A., and Raoult, D. (2002). Description of Afipia birgiae sp. nov. and Afipia massiliensis sp. nov. and recognition of Afipia felis genospecies A. Int. J. Syst. Evol. Microbiol. 52, 1773-1782. doi: 10.1099/00207713-52-5-1773 
Li, J. T., Zhang, S. H., and Hua, Y. M. (2013). Performance of denitrifying microbial fuel cell subjected to variation in $\mathrm{pH}, \mathrm{COD}$ concentration and external resistance. Water Sci. Technol. 68, 251-256. doi: 10.2166/wst.20 13.250

Li, W. Q., Zhang, S. H., Chen, G., and Hua, Y. M. (2014). Simultaneous electricity generation and pollutant removal in microbial fuel cell with denitrifying biocathode over nitrite. Appl. Energy 126, 136-141. doi: 10.1016/j.apenergy.2014.04.015

Logan, B. E., Aelterman, P., Hamelers, B., Rozendal, R., Schröder, U., Keller, J., et al. (2006). Microbial fuel cells: methodology and technology. Environ. Sci. Technol. 40, 5181-5192. doi: 10.1021/es0605016

Okamoto, H., Kawamura, K., Nishiyama, T., Fujii, T., and Furukawa, K. (2013). Development of a fixed-bed anammox reactor with high treatment potential. Biodegradation 24, 99-110. doi: 10.1007/s10532-012-9561-x

Puig, S., Marc, S., Vilar-Sanz, A., Cabré, M., Bañeras, L. L., Colprim, J., et al. (2011). Autotrophic nitrite removal in the cathode of microbial fuel cells. Bioresour. Technol. 102, 4462-4467. doi: 10.1016/j.biortech.2010.12.100

Van Doan, T., Lee, T. K., Shukla, S. K., Tiedje, J. M., and Park, J. (2013). Increased nitrous oxide accumulation by bioelectrochemical denitrification under autotrophic conditions: kinetics and expression of denitrification pathway genes. Water Res. 47, 7087-7097. doi: 10.1016/j.watres.2013. 08.041

Vanparys, B., Heylen, K., Lebbe, L., and Vos, P. D. (2005). Devosia limi sp. nov., isolated from a nitrifying inoculums. Int. J. Syst. Evol. Microbiol. 55, 1997-2000. doi: 10.1099/ijs.0.63714-0

Virdis, B., Rabaey, K., Rozendal, R. A., Yuan, Z., and Keller, J. (2010). Simultaneous nitrification, denitrification and carbon removal in microbial fuel cells. Water Res. 44, 2970-2980. doi: 10.1016/j.watres.2010.02.022

Virdis, B., Rabaey, K., Yuan, Z., and Keller, J. (2008). Microbial fuel cells for simultaneous carbon and nitrogen removal. Water Res. 42, 3013-3024. doi: 10.1016/j.watres.2008.03.017

Wang, Q., Feng, C., Zhao, Y., and Hao, C. (2009). Denitrification of nitrate contaminated groundwater with a fiber-based biofilm reactor. Bioresour. Technol. 100, 2223-2227. doi: 10.1016/j.biortech.2008.07.057

Wrage, N., Velthof, G. L., Van Beusichem, M. L., and Oenema, O. (2001). Role of nitrifier denitrification in the production of nitrous oxide. Soil Biol. Biochem. 33, 1723-1732. doi: 10.1016/S0038-0717(01)00096-7
Wrighton, K. C., Virdis, B., Clauwaert, P., Read, S. T., Daly, R. A., Boon, N., et al. (2010). Bacterial community structure corresponds to performance during cathodic nitrate reduction. ISME J. 4, 1443-1455. doi: 10.1038/ismej.2010.66

Xiao, Y., Zheng, Y., Wu, S., Yang, Z. H., and Zhao, F. (2015). Bacterial community structure of autotrophic denitrification biocathode by 454 pyrosequencing of the 16S rRNA Gene. Environ. Microbiol. 69, 492-499. doi: 10.1007/s00248-0140492-4

Xie, S., Liang, P., Chen, Y., Xia, X., and Huang, X. (2011). Simultaneous carbon and nitrogen removal using an oxic/anoxic-biocathode microbial fuel cells coupled system. Bioresour. Technol. 102, 348-354. doi: 10.1016/j.biortech.2010.07.046

Yamada, T., Sekiguchi, Y. S., Imachi, H., Ohashi, A., Harada, H., and Kamagata, Y. (2006). Anaerolinea thermolimosa sp. nov., Levilinea saccharolytica gen. nov., sp. nov. and Leptolinea tardivitalis gen. nov., sp. nov., novel filamentous anaerobes, and description of the new classes Anaerolineae classis nov. and Caldilineae classis nov. in the bacterial phylum Chloroflex. Int. J. Syst. Evol. Microbiol. 56, 1331-1340. doi: 10.1099/ijs.0.64169-0

Zhang, F., and He, Z. (2012). Simultaneous nitrification and denitrification with electricity generation in dual-cathode microbial fuel cells. Chem. Technol. Biotechnol. 87, 153-159. doi: 10.1002/jctb.2700

Zhang, L., Zhu, X., Li, J., Liao, Q., and Ye, D. D. (2011). Biofilm formation and electricity generation of a microbial fuel cell started up under different external resistances. Power Sources 196, 6029-6035. doi: 10.1016/j.jpowsour.2011.04.013

Zhao, Y., Feng, C., Wang, Q., Yang, Y., Zhang, Z., and Sugiura, N. (2011). Nitrate removal from groundwater by cooperating heterotrophic with autotrophic denitrification in a biofilm-electrode reactor. J. Hazard. Mater. 192, 1033-1039. doi: 10.1016/j.jhazmat.2011.06.008

Conflict of Interest Statement: The authors declare that the research was conducted in the absence of any commercial or financial relationships that could be construed as a potential conflict of interest.

Copyright (c) 2016 Zhao, Zhao, Li and Li. This is an open-access article distributed under the terms of the Creative Commons Attribution License (CC BY). The use, distribution or reproduction in other forums is permitted, provided the original author(s) or licensor are credited and that the original publication in this journal is cited, in accordance with accepted academic practice. No use, distribution or reproduction is permitted which does not comply with these terms. 